\title{
Not without family: refugee family entrepreneurship and economic integration process
}

\section{8}

Received 31 March 2020

Revised 17 September 2020 7 January 2021

Accepted 27 January 2021

\author{
Khizran Zehra
}

\author{
Tilburg School of Economics and Management (TiSem), Tilburg University, \\ Tilburg, The Netherlands, and \\ Sadia Usmani \\ Department of Public Administration, Fatima Jinnah Women University, \\ Rawalpindi, Pakistan
}

\begin{abstract}
Purpose - Refugee entrepreneurship is increasing because of the increased influx of refugees around the globe. This leaves us with the question that how refugees integrate economically in the host country in the presence of all social, emotional and economic constraints. Existing literature suggests looking into the role of social capital to address refugee economic integration, particularly in developing nations. To acknowledge this call, this paper aims to explore the impact of family social capital on the economic integration process. Particularly, this study has investigated the Afghan refugee entrepreneurial activities and the integration process of Afghan refugees in economic and social spaces in Pakistan.

Design/methodology/approach - The study is rooted in 18 in-depth interviews with five participants that run small businesses in the city of Rawalpindi in Pakistan.

Findings - The findings revealed Afghan refugee entrepreneurs, develop a different type of family social capital i.e. horizontal and vertical social capital. Afterward, when the acculturation pace up across refugees' generations then they accumulate bridging social capital gradually. The process of economic integration happens in different stages as also shown in the existing literature. Based on (Berry, 2003; Evansluong et al., 2019; Khulman, 1991) economic integration process this paper has discussed three main stages (entry in labor market, gradual integration and gradual sub-merging in host society) of Afghan refugee economic integration in Pakistan and further this study has shown how different steps are arranged within these stages to smoothen the integration process.

Research limitations/implications - With this research, this paper calls for a more nuanced approach to address the challenges that are faced by refugees during their economic integration. Future research on Afghan economic and social integration can contribute to a better understanding of refugee settlement, wellbeing and self-sufficient status in host countries. One of the limitations of the study is the focus on male participants because female Afghan refugees do not work mostly because of strong patriarchal structures observed in refugee Afghan groups.

Practical implications - Most Afghan entrepreneurs consider them as Pakistani and do not want to repatriate to Afghanistan. This provides an opportunity for Pakistani policymakers to provide regulations and opportunities to Afghan entrepreneurs who want to stay in Pakistan and contribute to their family wellbeing and economic income generation and employment in Pakistan.
\end{abstract}

(C) Khizran Zehra and Sadia Usmani. Published by Emerald Publishing Limited. This article is published under the Creative Commons Attribution (CC BY 4.0) licence. Anyone may reproduce, distribute, translate and create derivative works of this article (for both commercial and noncommercial purposes), subject to full attribution to the original publication and authors. The full terms of this licence maybe seen at http://creativecommons.org/licences/by/4.0/legalcode
Journal of Enterprising Communities: People and Places in the Global Economy pol. 17 No. $158-181$ Emerald Publishing Limited 1750-6204

DOI 10.1108/JEC-03-2020-004 
Social implications - The role of the family acts as a means to refugee entrepreneurs' integration in the host country. Strong migration networks and dense family configurations are a source of pride, responsibility, resilience and self-esteem for Afghan refugees to start and expand their businesses.

Originality/value - This study provides the opportunity to explore the under-researched role of family social capital in the migrant and refugee entrepreneurship literature.

Keywords Family social capital,, Refugee entrepreneurship,, Labor market integration, Refugee economic integration

Paper type Research paper

\section{Introduction}

Over the past decade, human migration has become an increasingly important and debated topic because of involuntary migrations and seeking formal status as refugees for protection (Mawson and Kasem, 2019). In contrast to voluntary migrants' refugees are individuals who had to leave due to a "well-founded fear of being persecuted for reasons of race, religion, nationality, membership of a particular social group or political opinion" (UNHCR, 2020). Another reason that has increased in fled of migrants across the globe is mainly due to ongoing wars or being in danger zones e.g. Afghanistan, Iraq, Somalia, Syria, Libya, etc. Among these displaced migrants across borders i.e. refugees, $68 \%$ of the refugees come from just five countries i.e. Syria, Venezuela, Afghanistan, South Sudan and Myanmar (UNHCR, 2020). The Geneva Convention 1951 is the international law that helps refugees in providing welfare rights and protection in host countries (UNHCR, 2020). Since 1951 UN has helped to protect 50 million-plus refugees in host countries.

In this regard, refugee migrants are different from voluntary migrants/immigrants particularly in motivation, skills, capital and due to the forced nature of migration (Bizri, 2017; Roth et al., 2012; Wauters and Lambrecht, 2008). Therefore, policymakers need to revise and make sound policies for the social, political and economic integration of refugees. It is increasingly important to understand and analyze how refugees can be best integrated socially and economically in their host countries (Ager and Strang, 2008).

Labor market integration, i.e. securing and maintaining any type of formal employment, has been identified as a primary goal (Battisti et al., 2019; Gericke et al., 2018) for reducing welfare dependency and improving refugee's well-being (Ward et al., 2001; Gericke et al., 2018). However, literature shows that entering the labor market successfully is a difficult journey for refugees and comes with several challenges. The existing literature on refugees' economic activities in host countries addresses different challenges and barriers that refugees face in seeking employment in their host countries (Bizri, 2017; Garnham 2006; Roth et al., 2012; Wauters and Lambrecht, 2008). Scholars recognize that barriers to seeking employment are more critical for refugee migrants than voluntary migrants. These difficulties such as uncertainty about legal status, skill gaps, language proficiency, lack of formal qualifications, traumatic stress, result in unemployment/under-employment among refugees (Vinokurov et al., 2017; Ward et al., 2001). As a result, refugees are often pushed into informal entrepreneurial activities to support their families financially and survive in a new environment (Mawson and Kasem, 2019), so entrepreneurship as the most popular career choice among refugees is inherent (Garnham, 2006). Most of the time this entrepreneurship is informal (Dana and Morris, 2007). These challenges force refugees to enter the formal markets mostly through small businesses and entrepreneurial activities which are influenced by their place and economic space (Dana and Morris, 2007; Ramadani et al., 2019; Sandberg et al., 2019). Entrepreneurship in the context of refugees is an important phenomenon but has received less attention in the existing literature despite

\section{Economic integration \\ process}


JEC

17,1

160

having relevance to policymaking at different levels i.e. local, national, international (Desai et al., 2020). To date, we know little about the entrepreneurial behavior of refugees in general and how they enter the labor markets, specifically integration of refugees in labor markets and on well-being of refugee migrants' families remains unexplored (Gericke et al., 2018). We do know that intact families (particularly those that include more than one breadwinner) generally have better prospects for achieving self-sufficiency as families can pool their resources and support employment activities (Ghufran, 2011). However, we know quite little about the role that families of refugees can play in facilitating refugee economic integration (Takeda, 2000). This question of labor market integration of refugees is important to understand as it implies that functional refugee families will have the less economic burden on host countries (Caarls and de Valk, 2017). Furthermore, local well settled and integrated refugee families are source and recipient of social traditions, culture and values and may also perform as an important entrepreneurial function (Elo et al., 2019) across generations to reduce inequality and marginalization effect (Beckers and Blumberg, 2013).

Family plays a pivotal role in providing support while settlement of individual refugees (Summerfield, 2001) and can be an important source to understand labor market integration (Bevelander, 2020). Family is a source of identity and is beneficial for the emotional health and well-being of a refugee (Farwell, 2001; Simich et al., 2003). Family is recognized as a resource and an institution for entrepreneurship, which provides a basis for trust, collective actions and a sense of community (Jack and Anderson, 2002; Aldrich and Cliff, 2003). The support of family can extend to different domains that could be moral support, financial support, emotional support, religious support, etc (Batrouney and Stone 1998; Manderson et al., 1998). Family can pass on important resources like cultural capital, human capital to their next generations through socialization (Dana and Light, 2011). The social capital that a family provides can smooth refugee integration by offering different resources for refugee settlement and survival in host countries (Bizri, 2017; Bevelander, 2020). Family social capital impacts entrepreneurial activities and provides important initial resources (Salvato and Melin, 2008). We know that family members engage in entrepreneurial activities (Aldrich and Cliff, 2003), provide financial support (Ram et al., 2008), provide social networks (Bizri, 2017; Bevelander, 2020). Conversely, if refugee families are not settled well or are separated then it can affect refugee health adversely leading to anxiety and depression (Schweitzer et al., 2006). For example, refugees associated only with closed networks lack social and economic resources within the host country (Lancee, 2016; Nannestad et al., 2008).

While the developments of migrant's previous research have shown effects of social capital on migrant careers (Haug, 2008; Lamba, 2003; Lancee, 2016; Piracha et al., 2016; Evansluong and Ramírez Pasillas, 2019), the research on the social capital of family available to refugees in the context of labor market integration particularly is limited (Bizri, 2017; Lancee, 2016; Li, 2004). This refugee social capital is also referred to as ethnic bonding social capital and could be developed horizontally and vertically (Gericke et al., 2018; Ryan, 2011; Ryan et al., 2016). Horizontal social capital refers to contacts who are similar in terms of location, with access to similar resources. On the other hand, vertical social capital includes contacts who belong to different social levels and have access to more valuable resources (Ryan, 2011).

Nevertheless, the importance of family unit in the settlement of refugees is well stated but we do not know that how refugee family can impact entrepreneurial activities among refugees. Our knowledge about how family social capital accumulates (horizontally and vertically) and how it impacts refugee labor market integration remains limited. Therefore, in this study, we explore how refugee families can influence refugee labor market 
integration in the host countries, particularly through refugee entrepreneurship. This question needs special attention in the context of developing nations as the host country, as no research to date details the impact of family social capital in refugee economic integration in a developing country.

Using Pakistan as an empirical setting, this qualitative study aims to contribute to the ongoing debate of refugee settlement. The study will investigate the impacts of family social capital on refugee entrepreneurial activities of afghan refugees in Pakistan. Pakistan has a high number of Afghan refugees, and therefore the context of the study is relevant in understanding the impacts of family social capital on the entrepreneurial activities of Afghan refugees.

This research will contribute to refugee entrepreneurship and migrant entrepreneurship literature. We have attempted to analyze the labor market integration of Afghan refugees through their family entrepreneurship. We have found that labor market integration happens gradually in three stages of entering the labor market, integrating into the labor market and sub-merging with the labor market. The social capital of families plays important role in this integration process (Evansluong and Ramírez Pasillas, 2019; Light and Dana, 2013). We also agree with Kloosterman (2010) that to reach as similation stage of the Afghan refugee integration process, structural integration is also necessary. Afghan families rely on large family structures and family remains their most important institution to provide shelter and resources (Blood, 2018). However, there is also competition over sharing of resources and inheritance. It is important Government of Pakistan intervene with appropriate settlement policies for Afghan refugees that are sustainable and promote legal assimilation of Afghan refugees in Pakistan. This will help not only Afghan refugees but also the Pakistani community as a whole to gain potential economic benefits from Afghan migrant entrepreneurial behaviors and skills.

\section{Theoretical background}

\section{Refugee entrepreneurship and family}

Refugees are involuntary immigrants who fled to other countries because of wars or because of different dangers based on ethnicities, race, religion, faith, etc., or because of any other threats to their life. Globally, the influx of refugees is increasing constantly in the past years but literature on refugee's integration in host countries' economic activities is scanty (Wauters and Lambrecht, 2008, 2008). Although many studies have explained immigration and entrepreneurship from different perspectives (Borjas, 1986; Clark and Drinkwater, 2000, 2010; Fairlie and Lofstrom, 2015; Fairlie and Woodruff, 2010; Krichevskiy et al., 2016; Lintner, 2014; Lofstrom, 2002; Singer, 2004; Vesely et al., 2015; Wang, 2010), literature on refugee entrepreneurship has been detailed enough (Bizri, 2017).

To understand refugee entrepreneurship better it is important to outline the characteristics of refugees that separate them from other immigrants. The fundamental difference between the refugees and immigrants is based on the motivations of their mobility to the host countries. Voluntary immigrants move to new countries to seek new opportunities and mostly for their desire of better life, while involuntary immigrants i.e. refugees move to new countries move to new countries or host countries for their survival against life-threatening situations and their main motivation is the safety of their lives and their families (Bizri, 2017). This mobility motivation also impacts mobility freedom among voluntary and involuntary immigrants. This refers to the different legal statuses of voluntary immigrants and refugees. The legal status of voluntary immigrants allows them to move to other countries or even back to their home countries. However, refugees mostly seek asylum, and therefore, their mobility freedom is restricted until they get some certain

\section{Economic integration \\ process}


legal status in their host country (Crawley and Skleparis, 2018). This also means that refugees are entitled to welfare rights and various allowances in their host country while voluntary immigrants are not entitled to such rights mostly (Crawley and Skleparis, 2018). Apart from legal status and motivations the traumatic experiences also act as an additional challenge for refugees to integrate into their host countries (Shneikat and Ryan, 2018; Shneikat and Alrawadieh, 2019). Overall, refugee entrepreneurs have additional challenges and barriers to start their businesses in their host countries (Wauters and Lambrecht, 2008).

In some recent pieces, scholars have emphasized the importance of refugee entrepreneurship and how refugees can survive in the host labor market (Alrawadieh et al., 2018; Bizri, 2017; Harb et al., 2019; Refai et al., 2018; Shneikat and Alrawadieh, 2019; Şimşek, 2018). Entrepreneurial behaviors of refugees are often rooted in a family business context where the entrepreneurs, employees and their families willingly exchange social capital (Bizri, 2017). A family reunion of the refugees is likely to draw on the networks acquired by family and friends of settled refugees in the dame host country, thereby improving labor market integration opportunities (Bevelander and Pendakur, 2014). It is in the family where entrepreneurial startups are incubated first (Steier, 2009). Family plays important role in promoting or hindering entrepreneurial behaviors by transmitting values, stories, information, social skills, etc (Bettinelli et al., 2014; Chung and Gale, 2009; Sorenson, 2014). Family can be a source of pooling different resources such as social capital (Bizri, 2017), human and financial capital (Chrisman et al., 2005), thus gaining a significant advantage because of familiness (Habbershon and Williams, 1999). Entrepreneurship is embedded in the family has a bi-directional relationship i.e. family influences entrepreneurial behavior and, in turn, the emergence of new entrepreneurial opportunities and organizations may influence families (Bettinelli et al., 2014; Randersson et al., 2015). For example, the Muslim Memon community in Pakistan is recognized as successful entrepreneurs and they promote their children to work for them in their business and pursue an entrepreneurial career (Muhammad and Dana, 2015; Dana et al., 2020). Parental entrepreneurship is likely to increase entrepreneurship among Swedish children up to 60\% (Lindquist et al., 2012). Family can be a source of resilience and motivation for entrepreneurs to accumulate more assets that their family members can inherit (Schreiner, 1999; Fong et al., 2007). Flexibility in entrepreneurial organizations is desirable by some entrepreneurs because of family caregiving responsibilities (Schreiner and Woller, 2003). In short, family is the source of resilience (Schreiner, 1999), support and assistance for entrepreneurial actions (Danes et al., 2010) or it can also be a source of extra responsibilities (Schreiner and Woller, 2003) and conflict (Randersson et al., 2015). Relying on this stream of family entrepreneurship (Nordqvist and Zellweger, 2010), we explore the important contributions of the role of the family in facilitating labor market integration in the host country (Pakistan) among Afghan refugees through refugee entrepreneurship.

\section{Family social capital and refugee economic integration}

To understand the challenges of business development in peripheral contexts, e.g. in the case of refugee entrepreneurship, it is necessary to explore three main interconnected elements: entrepreneurship, migration and family (Elo et al., 2019).

Economic integration. The term integration is defined in various ways, as for refugees the integration process is different from voluntary migrants (Simsek, 2018). For refugee entrepreneurs' different aspects of integration include social, cultural, structural and economic dimensions (Beckers and Blumberg, 2013; Crul and Pasztor, 2007). The socio-cultural integration in the host country reflects interpersonal relationships between refugee migrants and natives of the host country (Beckers and Blumberg, 2013; Crul and Pasztor, 2007). 
Structural integration refers to participation in core institutions of the society such as educational attainment, position in the labor market, residential integration (Rusinovic, 2006). These layers of integration of refugees in the host country are very important because of intergenerational disadvantages that can continue and persist in the second generation of refugees as compared to the native population (Rusinovic, 2006; Beckers and Blumberg, 2013).

On the other hand, refugee entrepreneurship literature draws attention to economic integration. Economic integration of refugees refers to labor market integration through employment, income generation through entrepreneurship (Bevenlander, 2020). Scholars argue that structural and socio-cultural integration also affects the economic integration of migrants (Kloosterman, 2010; Valenta and Bunar, 2010). Economic integration through entrepreneurship depends on both the individual circumstances of entrepreneurs and different social and institutional setups of the host society (Kloosterman, 2010). Both social and economic aspects are important and interrelated and facilitate each other as networks facilitate the business establishment and development and business helps to develop new social networks (Valenta and Bunar, 2010; Simsek, 2018; Cheung and Phillimore, 2014). Refugee populations are increasing rapidly around the globe but still, there is a lack of economic integration of refugees (Bevelander, 2020). The refugee entrepreneurial population is largely necessity-based entrepreneurs that are rarely innovative and therefore marginally profitable (Beckers and Blumberg, 2013). Kuhlman (1991) has shown a three-staged process of economic integration that starts with separation and goes on with integration and assimilation. Separation is a stage where refugees avoid interactions in the host country, while assimilation means that refugees want to be absorbed by the host country (Berry, 1997, 2001, 2003; Kuhlman, 1991).

Role of family social capital in the economic integration of refugees. Social capital is defined as a set of social resources such as social networks that individuals use to pursue economic and social goals in the host country $(\mathrm{Li}, 2004)$. Along the same lines, family social capital, which consists of the bonding ties and closed familial relationships is recognized as instrumental in providing resources to family businesses (Salvato and Melin, 2008). This category of social capital gained through the family is also considered crucial in the settlement of immigrants by providing necessary resources and networks both in the host and home country (Dana, 2001; Evansluong and Ramírez Pasillas, 2019). Family social capital typically refers to bonds of affection, obligation and responsibility and raises expectations of gift-giving and in-kind assistance (Salvato and Melin, 2008; Meister and Mauer, 2019). Nevertheless, family social capital is not only based on true kin that is kin related through blood or marriage but it also includes fictive kin that refers to social ties not related through blood or marriage (Moinolmoki, 2019; Voorpostel, 2013). Family social capital refers mainly to family and friends, i.e. members related by blood or marriage and other relatives. Therefore, family social capital could be further expanded to an unrelated person with whom one has a friendly relationship. Typically, fictive kin also accord to same resources and expectations as true kin (Moinolmoki, 2019; Voorpostel, 2013).

Coming back to refugee entrepreneurs, several studies show that how refugees integrate into the labor market of the host country using social capital (Bizri, 2017; Gericke et al., 2018; Morrice, 2007; Li, 2004). Refugee entrepreneurs heavily rely on the social capital of their families and friends (Bevelander and Pendakur, 2014) to facilitate and smoothen the integration process in the host country (Gericke et al., 2018). Refugee entrepreneurs largely rely on people from the same ethnicities because of their familiarity with the co-ethnics and non-familiarity with the host country (Alrawadieh et al., 2018; Shneikat and Alrawadieh, 2019). Ethnic markets are different from mainstream and niche markets, where ethnic minorities largely continue to stay intricately connected with the migrants from same

\section{Economic integration \\ process}

163 
ethnicities and do not look for broader mainstream markets (Barrett et al., 1996). This type of social capital that develops among similar ethnicities, the same culture is known as bonding social capital (Gericke et al., 2018). Ryan (2011) argues for a more nuanced approach to understand the social capital of refugee entrepreneurs, and thus have added an additional dimension of social location in the form of horizontal or vertical social capital. Refugee entrepreneurs if depending only on horizontal social capital i.e. ethnic enclaves then their chances of integration and growth can be compromised (Altinay and Wang, 2011). Scholars argue that the growth of refugee entrepreneurs remains restricted as migrant entrepreneurs remain confined to their own ethnic communities (Barrett et al., 1996). Ethnic markets are usually representing saturation of similar ethnic products and are less innovative and less competitive and customers with less purchasing power (van Doorn et al., 2013).

In this regard, vertical social capital is described as social ties among individuals with different social backgrounds who have access to different knowledge and resources, whereas horizontal social capital is defined as social ties among individuals with similar social backgrounds and with similar knowledge and resources (Patulny, 2015; Ryan, 2011). These social ties keep on accumulating and changing over the period and location (Ryan et al., 2016; Gericke et al., 2018). Scholars have speculated that while the first generation of refugee immigrants have fewer opportunities for social integration because of language barriers, the second generation of refugee entrepreneurs might break out to other markets because of social networks and better social integration (Rusinovic, 2006, 2008; van Doorn et al., 2013). In fact, a longitudinal study on 56 refugee entrepreneurs in the Netherlands found that second-generation refugee migrant entrepreneurs do not just operate in ethnic markets, but they operate in mainstream markets and are comparatively more successful (Rusinovic, 2008). Similarly, Beckers and Blumberg (2013) showed that second-generation refugee migrants are better socially integrated and are better educated in the host country.

When refugees arrive in their host countries, the lack of resources, social isolation, language barriers put them in marginalization effect (Dannefer, 2003) and lack of labor market integration opportunities can continue this effect across generations of refugees. Therefore, to improve the chances of labor market integration and growth and to lower the costs and risks refugee entrepreneurs can bond with the same ethnicities, backgrounds (horizontal social capital) and may also require bridging social networks with people of higher education and higher status (vertical social capital). In general refugee, entrepreneurship can facilitate both entrepreneurship and the integration of refugees in the host country (Wauters and Lambrecht, 2008).

\section{Study context and method}

This study is based on Afghan refugee entrepreneurs' case and the role their families play in their entrepreneurial activities.

Afghan refugee influx in Pakistan. Many Afghan refugees have migrated to Pakistan in the past three decades. This influx of the Afghan diaspora in Pakistan started back in 1978 when Muhammad Daud's government was overthrown by the democratic party of Afghanistan (Qureshi, 2018). This influx of refugees in Pakistan escalated after the Soviet invasion in 1979. Afterward, the Taliban gained control over Kabul in 1996 and the rest of the country by 1998 (Hasan, 2010). Taliban had a fundamentalist regime with restrictions to educational, social and cultural activities, particularly for women. This Taliban regime also motivated many Afghans to fled from Afghanistan. Finally post 2001 US invasion was the final wave of migration which resulted in massive Afghan migration (Hilali, 2002). These three decades of migration and displacement led to the emergence of the Afghan diaspora in Pakistan. In total, 6.3 million Afghan refugees migrated from Afghanistan. This Afghan 
diaspora is a transnational group spreading in different continents with a circulation of money, people, information, etc. across the globe. In the case of Pakistan, Afghani refugees belong to different tribes of Pashtuns, Turkmans, Tajiks, Uzbeks and Hazara (Hasan, 2010). A massive wave of Afghan refugees to Pakistan was employment incentives and higher incomes. These continuing waves of Afghan refugee migration helped in establishing social linkages even before the Soviet Union. Afghan refugees were always warmly welcomed by Pakistan in the spirit of neighborhood and Muslim solidarity.

However, this spirit of welcoming Afghan refugees was reduced over time because of various reasons. First, as these Afghan refugees' families migrated to Pakistan there was a need for more resources to accommodate these refugees. Pakistan itself was struggling for the prosperity of its people after the 1971 war. Also, there was the issue of recyclers that was observed occasionally, in which Afghan refugees keep coming back for claiming extra rights and benefits even if they can settle on their own (Qureshi, 2018). Since 2010 Afghan repatriation from Pakistan to Afghanistan has increased (Alimia, 2014)

Relevance of empirical context. Afghan refugees have been accepted and received in Pakistan with open arms for three decades now. However, insecure legal status and limited access to rights in practice are influencing their smooth integration in Pakistan as a host country. Afghan refugees do not find many opportunities for jobs, first because of being refugees, second, they do not possess proper legal documentation and third due to lack of education. However, they were very skilled people with a lot of motivation to live a better life. Therefore, self-employment and entrepreneurship appealed to many Afghan refugees as entrepreneurship holds special potential for those who have been disadvantaged in some way in the labor market (Edgcomb et al., 2007; Toussaint-Comeau, 2005). In Pakistan, this holds true for the Afghans they used their skills and start their small venture with the help of their families. The family remains the most important institution among Afghans (Blood, 2018). Even with lots of chaos in past decades family and ethnic networks are given lots of respect in Afghan society. Therefore, newly arrived Afghan refugees always find shelter with families already established in Pakistan, resulting in further larger families of more than 20 people commonly (Blood, 2018). There can also be conflicts, competition over inheritance, etc. There have been reliable and relevant sources concerning migration routes of Afghan refugees, but the role of the family has not been examined in refugee entrepreneurial activities.

Data collection. The data were collected from field research mainly through interviews conducted during December 2019-February 2020. Based on the interviews that were carried out based on a semi-structured interview guide, significant firsthand data was gathered. The data was collected in two rounds of interviews, the first 10 interviews in December 2019 and eight interviews in January-February 2020. All interviews are conducted in the city of Rawalpindi in Pakistan. The number of Afghan refugees has surpassed 35,000 in Rawalpindi alone (Daily Times, 2016). The Afghan refugees settled in district Rawalpindi are divided into three categories. Refugees who have been issued cards from UNHCR, Afghan refugees who have obtained Pakistani National Identity Cards (NICs) illegally from NADRA [1] and Afghan refugees who have no proof of identification (Daily Times, 2016). All participants were selected through snowball sampling. Purposive sampling is not easy as Afghan refugees do not want to be identified as Afghans because of their illegal status and risk of repatriation. Instead, Afghan refugees identify themselves as Pathans [2] and Pakistani. Therefore, we only used our personal references to reach our sample respondents. The interview lasted $70-90$ min on average and was conducted on themes such as migration reason, migration year, migration generation, migration experiences, family configurations, business origins, development and use of migration networks, the role of family, host 
country challenges, repatriation, etc. All interviews were conducted face to face by the second author and were recorded on phone and transcribed and cross-checked by both authors.

For our study, we have five cases of Afghan refugee entrepreneurs who have different tribes and different languages from each other. These Afghan markets in Rawalpindi are saturated by male Afghan entrepreneurs, who have dominated the cloth market, carpet market, street food market in Rawalpindi and Islamabad. We did not witness any Afghan female entrepreneurs particularly in these markets because of patriarchal norms and family structures of Afghan refugees, which we understand is a big limitation but still gives us an overall understanding of Afghan family structures and what role men and women are assigned in these family configurations. These Afghan entrepreneurs are living in Pakistan for more than 20 years. Some are here in Pakistan, as their birth and have their fourth generation in Pakistan still as a status of an Afghan refugee. Pakistan does not offer citizenships to Afghan refugees currently; therefore, all these participants are sharing informal and self-creating fewer regular spaces.

In Table 1, we have shown the characteristics of the participants that describe our empirical context. The participants were Ramani, Mir Wazir, Noor Shah, M Rasool and Zarwali. All participant's elders moved to Pakistan because of bad economic and bad civil conditions in Afghanistan. Pakistan. Pakistan welcomed Afghan refugees since the 1970s, therefore now Afghan refugees have their small businesses in bigger urban cities of Pakistan.

Data analysis. To make sense of our raw data we began with transcription of data. To analyze the transcripts we started with coding, i.e. to analyze data and make categories into simple or complex codes (Miles and Huberman, 1994). This categorization of data into codes started with themes to understand the phenomenon of refugee integration and for the purpose of theory building (Miles and Huberman, 1994; Seidel and Kelle, 1995). We used Gioia and Pitre (1990) method to develop first order, second order and aggregate dimensions by attempting multiple analyzes. The data analysis consisted of five stages of data organizing, case descriptions, developing first and second-order codes and aggregate dimensions (Gioia et al., 2013). Data analysis is the result of continuous data iteration and back and forth movements between data and theory (Gioia et al., 2013; Marshall and Rossman, 2014). To develop the codes, we read the transcripts and listened to the interview audio files multiple times. It helped in identifying different stages of integration of refugee entrepreneurs over the years in Pakistan. It also helped in understanding different activities that are arranged by refugee entrepreneurs to enter the informal economy. First, some prior codes reflecting the themes of the interview guide were created, i.e. thematic coding. This is a deductive way of creating themes from the interview guide and is especially helpful when we have multiple participants (Lapadat, 2009). The iteration of coding continued and in the second cycle new dimensions and direction from the prior codes. This refining of codes was extremely helpful in the construction of analysis and defining theoretical choices. This iteration was conducted in cycles until some thematic saturation was achieved at the coding stage (Eisenhardt, 1989) and finally aggregate dimensions were extracted. Table 2 shows the data structure and themes extracted. The data structure in Table 2 shows the aggregate dimensions in the form of the integration process observed in refugee entrepreneurs (respondents of the study). The integration process usually involves different stages, in which separation and assimilation are two extremes if place on a continuum. Separation is the situation where refugee migrants have no link to host country natives, but assimilation is a positive extreme that refers to the situation where natives and refugee migrants coexist (Berry, 1988; Kuhlman, 1990). However, in our case, we did not observe any of this situation 


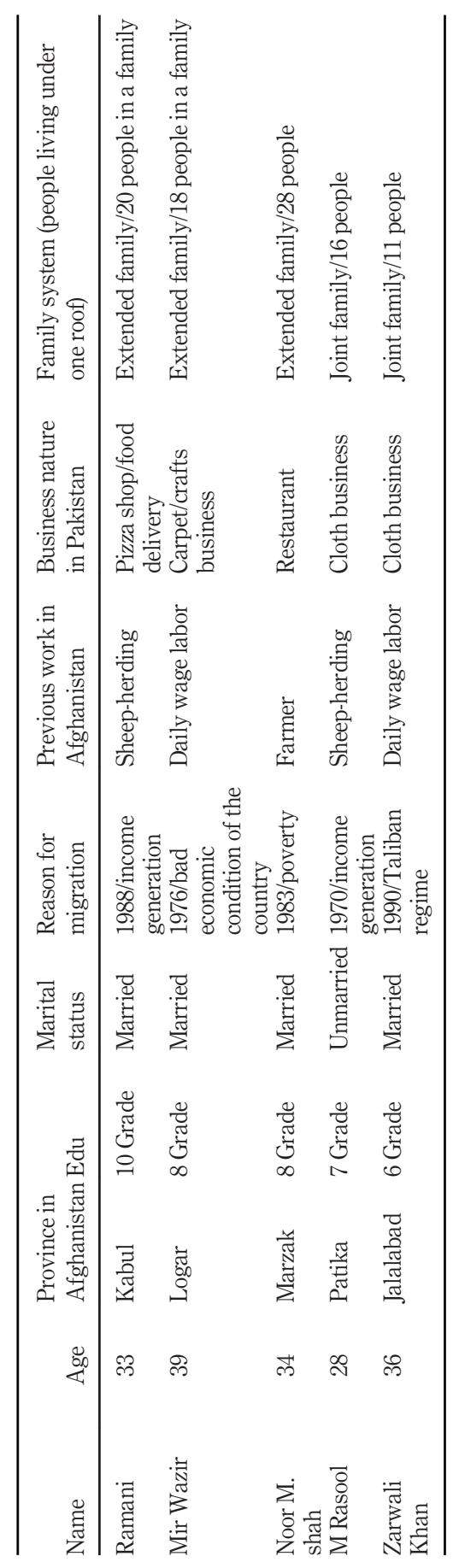

Economic integration process

Table 1 Participants' characteristics 


\begin{tabular}{|c|c|c|c|}
\hline First-order & Second-order & Third-order & $\begin{array}{l}\text { Integration } \\
\text { process }\end{array}$ \\
\hline $\begin{array}{l}\text { Trauma } \\
\text { Stress } \\
\text { Insecurities } \\
\text { Lack of confidence } \\
\text { Unemployment/ } \\
\text { underemployment } \\
\text { Lack of education } \\
\text { Competitive formal market } \\
\text { Lack of trust } \\
\text { Huge informal market of } \\
\text { Pakistan }\end{array}$ & $\begin{array}{l}\text { Immediate family attachment } \\
\text { helps in dealing with negative } \\
\text { emotions } \\
\text { Nuclear family configurations } \\
\text { demand means to survive } \\
\text { Family business is preferred } \\
\text { Family members work for } \\
\text { their business } \\
\text { Informal businesses are } \\
\text { started }\end{array}$ & $\begin{array}{l}\text { Resilience } \\
\text { Survival instincts } \\
\text { Forced to informal } \\
\text { business } \\
\text { Family business is } \\
\text { inherited to } \\
\text { generations }\end{array}$ & $\begin{array}{l}\text { Entering labor } \\
\text { market }\end{array}$ \\
\hline $\begin{array}{l}\text { Increase communication and } \\
\text { interaction with ethnic networks } \\
\text { in other cities } \\
\text { Cheap labor } \\
\text { Business collaborations } \\
\text { Increased trust } \\
\text { Job opportunities in } \\
\text { Afghan businesses } \\
\text { Informal training and advice } \\
\text { Networks }\end{array}$ & $\begin{array}{l}\text { Migration networks providing } \\
\text { with resources } \\
\text { Increased access to locations } \\
\text { and spatial networks }\end{array}$ & $\begin{array}{l}\text { Afghan refugee } \\
\text { migration network } \\
\text { Social ties in } \\
\text { sparse locations }\end{array}$ & $\begin{array}{l}\text { Support from } \\
\text { ethnic refugee } \\
\text { networks }\end{array}$ \\
\hline $\begin{array}{l}\text { Local help for legal matters e.g. } \\
\text { tax, bails, etc } \\
\text { Afghan refugee generations } \\
\text { learning the language } \\
\text { Celebrating/adopting local } \\
\text { Pakistani traditions } \\
\text { Local social ties } \\
\text { Entering to local education } \\
\text { institutes }\end{array}$ & $\begin{array}{l}\text { Local community developing } \\
\text { trust } \\
\text { Accepting Afghan refugees as } \\
\text { one of them (slow process) } \\
\text { Afghan refugee young } \\
\text { generations consider them } \\
\text { Pakistanis }\end{array}$ & $\begin{array}{l}\text { Pace of } \\
\text { acculturation }\end{array}$ & $\begin{array}{l}\text { Developing } \\
\text { bridging ties }\end{array}$ \\
\hline
\end{tabular}

we found that refugee entrepreneurs are residing in Pakistan, for decades, and therefore they have reached the stage where they are sub-merging gradually with natives. This has taken 40 years of struggle for Afghan refugees and now second and even third generations of these refugees are trying to settle in Pakistan. In retrospection, entry into the Pakistani labor market was always facilitated through family support. Afghan families are quite large and they have commonly joint family structures that can exceed even 25-30 members in one household. This large family structure helps in providing important family social resources in the form of moral strength, advice, emotional support, free labor, work-sharing, etc. Over the years respondents show they develop vertical links in the form of ethnic networks to get help with taxes, language, education, etc.

\section{Findings}

The refugee entrepreneurs in our sample had access to horizontal social capital which helped Afghan refugee entrepreneurs in smooth integration in Pakistan. This category includes family, friends and acquaintances from the same ethnicities. Family members and friends living in Pakistan served as the most important resource for Afghan refugees upon their arrival in Pakistan. Most of the refugee entrepreneurs relied on family ties and 
networks with similar status and background. Our respondents informed us that they got the most help from those acquaintances who were living in Pakistan for many years. The presence of vertical bonding affects the decision to stay location. For example, most of the Afghan refugees in Pakistan are enclaved in the city of Peshawar. They have started their business on an exceedingly small scale but with the passage of time, they are now living a relatively better life here in Pakistan, as compared to the life back in Afghanistan. Afghan refugee entrepreneurs have easy access to family social capital which is developed both horizontally and vertically. It is also observed that family social capital can also help refugee entrepreneurs to develop bridging social capital to access external resources.

\section{Afghan refugee economic integration process}

Afghan refugee economic integration in Pakistan be series of steps that are evident from our respondent's views shown in Figure 1. According to Figure 1, we can see three main stages of labor market integration of Afghan refugees studied in our research. We did not observe separation and assimilation stages as suggested by Berry (1997, 2001, 2003), Kuhlman (1990). Instead, we have seen that Afghan refugees have entered into Pakistani labor market largely through the route of necessity-based entrepreneurship. This process of refugee entry in the labor market integration of Afghan refugees is facilitated by family social ties that are developed horizontally and vertically (Gericke et al., 2018). During this Afghan refugee integration family, the social capital of refugees accumulates over time and paves the way for integration. Integration of Afghan refugees is processual and gradual.

The process started long ago with trauma and stress when Afghan refugees were received in Pakistan as the host country. At that point, they were separated from their home country and extended families, friends, etc., but this separation was not massive in Pakistan because many Afghan refugees were settled from years in Khyber-Pakhtunkhwa (KPK) and they helped the new Afghan refugee migrants in surviving in the host country. Also, the local Pashto language of Pakistani natives in KPK was common in Afghanistan. Therefore, the strength of their close family ties i.e. horizontal family social capital helped Afghan refugees in getting out of traumatic conditions. Family attachment promotes resilience and increases survival instincts in the host country. The horizontal social capital of the family helps with tangible and intangible resources. Family social capital (horizontal) helped with well-being and provided initial resources for starting informal businesses e.g. administrative

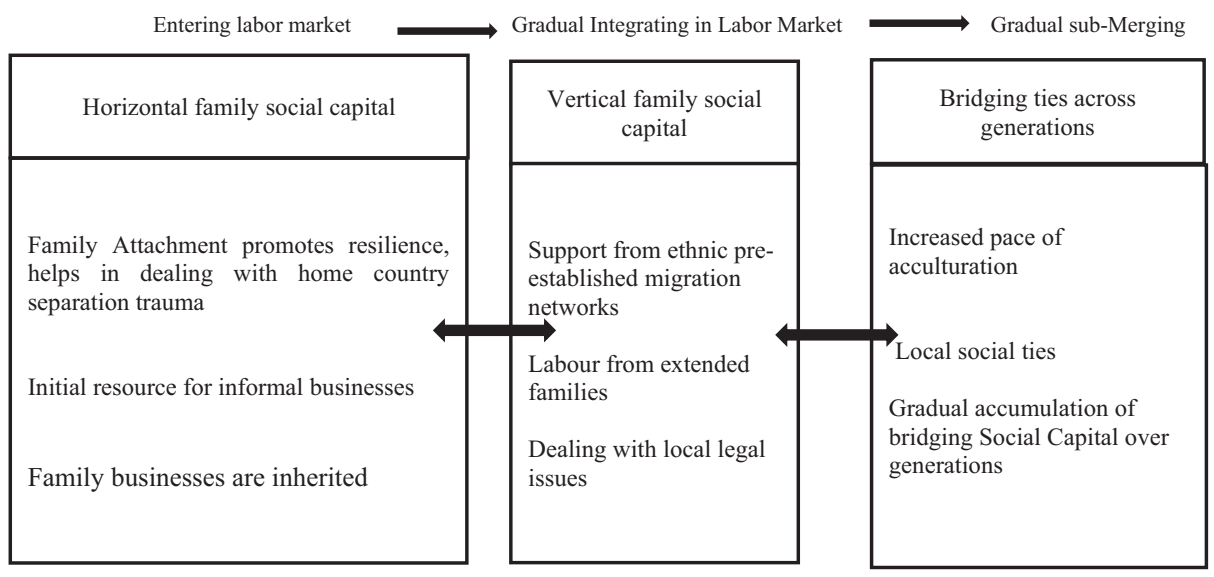

\section{Economic integration \\ process}

169 
support, cheap labor, etc. This gradually started the process of integration of refugee entrepreneurs that spread over decades. On these factual bases, we conclude that the separation element as explained by Kuhlman (1990) was not extraordinarily strong in the case of Afghan refugees in Pakistan because of cultural, religious similarities and the same language. In Figure 1, it is shown that Afghan refugees further got help from vertical family social capital (extended ethnic networks) for additional support for their businesses. Finally, across the generations, Afghan refugees' children increase their pace of acculturation by developing local language, traditions and social interactions with the local community. Over the generations, Afghan refugee children have helped in developing bridging capital and social ties with the local community and are moving toward the submerging stage.

\section{Process of refugee economic integration}

\section{Step 1: Entering the labor market}

Family attachment promotes resilience. Refugee entrepreneurs typically aim to have a better life for their families. We found that Afghan participants reflected that in their communities' people have extended families which are quite big e.g. Noor Shah have 28 people in his family that are living under one roof; "I have big family [. . . ] I work seven days a week [...]I need to support them" (Noor Shah). While some have joint families including parents and brothers' families but not their aunt and uncles e.g. Afghans take responsibilities for their families, no matter what e.g. Zarwali shared "I cannot leave my work [...] I have my parents, wife and children at home [.. .] they depend on me" (Zarwali). Likewise, Rasool has such family arrangements; all his aunts and uncles are considered family according to their religious faith; "You have to earn for your family [. . .] my family takes pride in me [...] I started working with my father from 12 years" (Rasool). All financial responsibilities are with men in Afghan culture, while women take care of their house chores; "I cannot give my kids any time because I am the bread earner [ . . . I must manage all the financials [...] my family is very caring; they have minimal expenses" (Wazir). The women i.e. daughters or sisters marry and leave their homes and live with their in-laws. Family affiliation and attachment play an important role in adaptation in the host country. The family remains the main source of resilience and motivation against any odds; "We have to work for our women $[\ldots]$ our poor women cannot work because they are not educated [...] they trust on us and we have to prove ourselves" (Ramani).

Informal family businesses because of high insecurity concerns. As a result of not many job opportunities, lack of education and language barriers Afghan refugees are forced to work in the informal economy. The labor market is competitive and yet Afghan refugees must survive and manage the expenses of accommodation, family expenses, etc. Therefore, they prefer to start informal small ventures that usually runs in the family if it is successful; "We do cloth business [. . . ] business is just because it is religious and its Sunnah of Hazrat Muhammad (PBUH) [... . we started from selling clothes on cycle" (Rasool). Afghan refugee entrepreneurs have either inherited their business from their elders or they intend to transfer it to their children:

Ancestors came and settled first and then we were reunited and we joined our father's business of cloth [... . who started it from selling cloth on installments and use to go on cycle (Zarwali).

All the businesses are running in families and all male members share and work for their business; "I inherited this business from my father" (Ramani). "Our children will also work in this business" (Wazir) and this is because of no opportunity available for personal or business registration for Afghan refugees in Pakistan. A strong sense of insecurity is 
prevalent among all Afghan refugee communities. This insecurity is because of lack of legal status in Pakistan which translates into bigger problems such as a license to operate businesses, registration of shops, personal registrations, purchasing any kind of property, studying, public jobs and work permits. For example, Zarwali shared that, "we cannot go any further from this [...] we cannot travel, we cannot study, we cannot buy property [...] do nothing" (Zarwali) This limits their growth potential of their businesses and prosperity of their family members. Their women cannot study, and therefore stay home, their children also do not study and start working at their family businesses from childhood. Afghan refugees consider them Pakistani and demand rights as natives; "It's our right to get citizenships [...] we are here from 40 years but still no luck" (Ramani). Further, Wazir reflected on the intergenerational disadvantaged loop because of no legal status in Pakistan; "Our kids cannot study here [...] because we do not have Identity cards allowed here in Pakistan" (Wazir). This inequality leads to delayed economic integration processes and continuous discrimination; "People with Pakistani passport are now big businessman [...] but we are still struggling" (Noor Shah). Afghan refugees want to expand their businesses in different cities but it is not possible because they lack legal status; "We lack legal documents. We have no document to formalize [...] now we have investments, but we cannot get inventory from China and Singapore" (Rasool). This intergenerational disadvantaged status puts Afghan refugees under constant pressure; "Our children [. . .] Our women cannot study $[\ldots]$ they do not do anything [...] they just sit homes" (Ramani).

\section{Step 2: Gradual integration in the labor market}

Developing businesses through vertical family social capital (ethnic migration networks). In this study, our participants said that their ancestors arrived in Pakistan to take advantage of their pre-established migration networks i.e. through their friends or family members already in Pakistan.

The unrest situation and Afghan war has destroyed everything and has forced us to immigrate to Pakistan and has lowered down our living standards and dragged us into severe poverty. We left our homeland to save us and in search of better living conditions and to uplift our standards of living.

This is Zarwali an Afghan refugee informal entrepreneur in Pakistan sharing his family background and motive to flee from Afghanistan. For Zarwali things were surprisingly better in Pakistan. He recalled that he had no problem adjusting to Pakistan. He had friends in Pakistan who helped him with almost everything in setting up his business:

My father could not find any job, my friend told me to start my own work [... I I started cloth business at a small scale with the borrowed money [. . . My Pakistani friend helped me. Financial and moral (Zarwali).

While explaining the reason for the migration of his ancestors, Noor Shah shared that:

There were no jobs, no income in Afghanistan, our relatives were in Pakistan and they told my grandparents to move to Pakistan [...] my ancestors came here to find jobs and income (Noor Shah).

Community help as shown by Dana et al. (2020) is quite prevalent in Pakistan. The same was observed here, our respondent shared that:

We cannot survive without our own community's help [...] it is impossible for us to stay in Pakistan if we do not help other Afghan brothers because we do not have any legal status here [... . we are only considered as refugees even if consider Pakistan our home (Mir Wazir).

\section{Economic integration \\ process}


JEC

17,1

The Afghan community relies on family and ethnic networks largely to exchange resources and strengthen their entrepreneurial agency:

We have strong networks within our community [. . . we do not fight with each other and support each other in all aspects [...] because we have no legal status here in Pakistan [...] we are refugees [...] if we fight, we will go to jail and no one will bail us out [...] so we stick together (Rasool).

These examples illustrated in the quotes above show supports from migration networks is crucial in entering the economic path and setting the foundation for refugee small ventures. The support mostly came from refugee Afghan networks that were already settled in Pakistan. The sense of solidarity among Afghans personal migrant network is high and they always provide emotional support; "I used to sit on my friend shop Lahore and learned everything from him [... . my father gave me money and advise to do cloth business [...] My father gave me 70,000 PKR and started my business" (Ramani). They also help financially but, as Afghan refugees are mostly in a struggling period still, therefore the financial support is usually limited and networks of suppliers and markets are not very efficient.

Cheap labor from (extended) family. To keep the risk and expenses low, participants used their family members or their community members i.e. Afghan refugees only at minimal wages; "Even in this cloth market only [. . . my 4 to 5 families have businesses here and all the employees they have are Afghans" (Rasool). The business is handled by family members and inherits to the family members, "I and my brother work together [...] my three sons will also sit in this shop when they grow up" (Noor Shah). This enables them to live and work comfortably and also helps in transferring the entrepreneurial skills to the next generation through family (parental) entrepreneurship (Muhammad and Dana, 2015; Dana and Light, 2011; Dana et al., 2020). In addition to the low expenses, Afghan labor is only preferred by the participants because of the underlying characteristics of personal migration networks. Participants from the start of their businesses used their family members e.g. children, brothers, friends, friends' families for their work; "Our children or male family members help us in our work, this is easy and fewer wages required" (Mir Wazir). Participants simply had more contact with other Afghans seeking job opportunities and the common backgrounds, ethnicities and same language backgrounds facilitated this hiring of labor from extended family and migration networks; "We prefer Afghan employees because we know each other and can communicate effectively" (Zarwali).

\section{Step 3: Gradual sub-merging in the host economy}

Pace of acculturation across generations. Our findings showed that participants children learned Urdu (Pakistan language) and local Pakistani customs faster than their parents; "We have good relations with local Pakistani community [. . . because we are born here and we are happy and lucky than our elders [...] our elders had very difficult life" (Ramani). However, parents and elders of the family still have not acculturated and continue to practice their home country customs; "Our children are friends with Pakistani children [...] they love Pakistan [...] they do not think that they are Afghanis" (Rasool). In this situation's children help their parents in interpretation and are also better integrated with the local community and play important role in connecting their parents to the host community; "Our ancestors had a lot of problems [...] they live like cattle [...] but we are lucky [...] we are Pakistani [...] We care more about Pakistan [. . .] we know nothing about Afghanistan" (Mir Wazir). Afghan generations of refugee migrants want to be assimilated with the Pakistani community and do not want to repatriate to Afghanistan; "People gave space for shops [... ] even if we have no Identity cards [. . . We do all wedding rituals and cultural activities as in 
Pakistan [.. . ] there is no going back now" (Zarwali). Afghan refugees are not happy with the Government of Pakistan decision for repatriation, but they respect the native population for their help and respect for Afghans, "People here in Pakistan welcome us warmly always $[\ldots]$ they respect us [...] they did not take any rent from us when we live in Peshawar for 26 years" (Ramani). Afghan refugees demand better integration in Pakistani society through relax government policies for them. They do not want their children to feel displaced again, "Our children consider Pakistan as their home [...] they say they are Pakistani [...] they are better in Urdu language and help us in our businesses" (Noor Shah).

\section{Analysis and discussion}

The role of the family in refugee entrepreneurship cannot be understood without knowing the principal pathways of family configurations and structures in Afghan refugees (Dhami and Sheikh, 2000). Afghan refugees are mainly practicing collective standards that reflect lots of interdependence between individual and family roles. This means that the roles and expectations of individuals in the Afghan diaspora are tightly embedded in family structures and hierarchies. Afghan refugees practice strong patriarchal positions in their homes. There is great variation in the configuration of Afghan patriarchal families. Broadly speaking, traditional Muslim families commonly regard the extended families as part of the core and often span three or more generations (Dhami and Sheikh, 2000). For Muslim societies, great importance is attached to the family unit as such that family unit is considered as the foundation of a balanced and well-functioning society (Dhami and Sheikh, 2000). For Afghans, the nuclear family is the most reported household unit (McDonald-Wilmsen and Gifford, 2009; Griffin, 2002; Blood, 2018). This could be compound family (senior women e.g. mother/grandmother succeeding father or senior patriarchal head of family) (McDonaldWilmsen and Gifford, 2009; Griffin, 2002) or there could be extended family units that may include several to many households (McDonald-Wilmsen and Gifford, 2009; Griffin, 2002).

These strong patriarchal pathways in Afghan family configurations emphasize the strong family attachment and affiliation in Afghan refugees that led to an accumulation of horizontal family social capital. Therefore, the role of the family is central in understanding refugee entrepreneurship. Family acts as a source of positivity and provides strength against the trauma of leaving home country and separation from natives. Refugee entrepreneurs face multiple obstacles linked to their business start and settlement. However, all the obstacles affect refugees' entrepreneurs' involvement and resilience capacity and an essential component in resilient entrepreneurial activity among Afghan refugees is their family unit. The lack of legal status and lack of work and education opportunities necessitates Afghan refugees to embrace the multiple layers of complexities toward the path of survival as they believe that they do not have any other option but to persist and work hard for their families. Afghan refugee entrepreneurs create safe economic space by recognizing structural and cultural barriers that impede entrepreneurial growth. Most of the Afghan entrepreneurs maneuver within local constraints in the host country and enter the informal market and mostly start businesses that do not require legal licenses e.g. small shops, clothing business, hair salon, etc. The resource that is required in an early startup is mostly arranged by family including savings, moral support, labor, etc. Horizontal family social capital is crucial in standing up against all odds in the host country both emotionally and economically. This entry to informal markets allows Afghan refugee entrepreneurs to reject marginal status and prepare for early economic integration in the host country.

Migrant entrepreneurs sustain and create family configurations and ties with other individuals in the place of origin and the place of residence (Evansluong and Ramírez Pasillas, 2019). Apart from strong family affiliations and horizontal family social capital,

\section{Economic integration \\ process}


JEC

17,1

Afghan refugees also accumulate vertical family social capital i.e. Afghan migration networks in different locations within Pakistan (mostly) to get support for their businesses. These migration networks provide financial resources, moral support, informal training, advice, networks, etc. Entrepreneurs with no networks struggle and have little or no access to resources. These migration networks are mostly comprising networks of family, friends and extended family in the Afghan diaspora. Afghan refugees are heavily relying on their networks comprising true and fictive kin that include family, friends, business partners, clients, suppliers, laborers, etc. They live with their families, work with their families or with people from their Afghan community (Harb et al., 2019). Family male members e.g. spouses, siblings or family teams engage in entrepreneurship (Discua Cruz et al., 2013). Migrant entrepreneurship scholarship mentions that migrants maintain strong contacts with their home country families and networks also develop new networks in the host country (Evansluong et al., 2019). However, some scholars argue that migrants reduce interaction or terminate connections to their home country in search of a better life in the country of residence (Park and Waldinger, 2017. In our study, Afghan refugee entrepreneurs lack strong networks in the host country, but they have their personal social networks in the Afghan migrant community in Pakistan (Qureshi, 2018). Nevertheless, participants in this study showed that the acculturation across generations is pacing and Afghan generations are now closer to the local community than ever. The locals from the host country always support Afghan refugees even if the Pakistani refugee law is not in the refugee's favor. Pakistani refugee law does not allow Afghan refugees to get registered and apply for Pakistan National Identity cards and this increases the sense of insecurity among refugee entrepreneurs as they cannot register their businesses and even themselves in Pakistan. They have Afghan cards which do not allow Afghan refugees to purchase property (shops, cars, homes, etc.), their children cannot study, their women are uneducated and stay home. This feeling of insecurity and lack of legal measures forced afghan refugee entrepreneurs to focus resiliently on their businesses as this is the only survival opportunity they have.

In this study, we also found that patterns of acculturation among Afghan refugees are different in generations. For example, our findings showed that the pace of acculturation is faster in youth and young children as compared to their elders and ancestors. The interaction with locals from the host country speeds up acculturation (Taras et al., 2013). Conversely, a lack of contact with the host culture may not only slow down the integration process but even reverse it and in some situations, it can also be negative acculturation (Taras et al., 2013). While we expected that most refugee entrepreneurs would interact and integrate with locals from the host country, but in our study, we observed that this pace is only speeding up in young generations. The elders and ancestors of Afghan refugee entrepreneurs rejected the social and cultural values of the host country. Therefore, the speed of assimilation is gradual and slow for Afghan refugees. The findings are surprising because Afghan refugees were most welcomed in their first and second wave of migration to Pakistan and now after the third wave this warm wishes and spirits are just outlived in the Pakistani community. We believe that this pace of acculturation is faster in Afghan youth because they are born in Pakistan and they know the local language i.e. Urdu very well and this helps them to integrate and know the local culture better than their elders. The youth born and brought up in Pakistan do not want to move back to Afghanistan as most of them are in Pakistan from their birth and it has been more than 20-30years that they are in Pakistan. These Afghanis do not consider them Afghanis anymore. Their family rituals and cultural activities are largely influenced by Pakistani culture. They even prefer to call them Pakistanis and know nothing about Afghanistan. There are no laws addressing their living, but refugee entrepreneurs prefer to keep their business practice clean and orderly for the 
sake of their families and do not want to run the risk of being stopped from running their businesses. There are no incidences of fights or inappropriate behaviors by these Afghan entrepreneurs and their bridging networks as they know that they are privileged in their host country and their general attitude is to focus on their businesses and avoiding unnecessary problems (Harb et al., 2019). These refugees' entrepreneurs mentioned clearly that they want to stay always in Pakistan and their families to stay here.

\section{Conclusion}

Afghan refugee entrepreneurs have diverse and rich experiences of entrepreneurship, that can add to our understanding of the merits and challenges of refugee entrepreneurship. Further, family configurations and ties might exercise an influence on entrepreneurial activities and processes, but this potential is still left unexplored (Aldrich and Cliff, 2003). This study attempted to understand the role of the family in understanding refugee entrepreneurship which is a multidimensional and multilayers phenomenon. Studying the role of the family in refugee entrepreneurship allowed me to look at the culturally informed perspective that looks at collective context. A family-focused approach to refugee entrepreneurship offers an understanding of multiple layers of refugee entrepreneurship from exile to resettlement, from separation to the reunion, from sufferings to resilience. It was indeed a privilege for us to witness these resilient personal and entrepreneurial experiences of refugee entrepreneurs. These findings need to be explored in other refugee entrepreneurship contexts to understand the role of family and refugee entrepreneurs' experiences in maintaining and growing their ventures. The interdependence and interconnectedness observed in Afghan refugee families and networks need to be further explored.

The status of forced immigration in case of refugee migrants push refugee migrants to further marginalized position as compared to voluntary labor immigrants (Beckers and Blumberg, 2013). The integration of refugees in labor markets depends on social, structural integration, that is education, language, interpersonal relationships with natives can hinder/ enhance the integration process of refugees in host countries (Bevelander, 2020). If the circle of marginalization continues in refugee migrants then the coming generations also suffer disadvantaged status as compared to the natives (Beckers and Blumberg, 2013). Refugee entrepreneurship scholarship needs to acknowledge the rich context of family entrepreneurship among refugees that can strongly influence the refugee integration process. Given the increasingly high levels of refugees around the globe, there is a dire need to focus and embrace this important area of study in the migration entrepreneurship literature.

With this study, there are certain policy interventions that are identified to address the barriers faced by entrepreneurial refugees. This study sees the need for legal measures for those Afghan entrepreneurs who do not want to leave Pakistan and have their businesses settled in Pakistan. These legal measures are access to registration opportunities in Pakistan that will allow Afghan refugees to register themselves and their businesses in Pakistan, with more open access to economic infrastructure. There are many countries that offer permanent legal status to refugee migrants and assist in the settlement of refugees in host countries (Martín et al., 2016). This policy intervention is important not only for Afghan refugees but also for Pakistan as these skilled refugee entrepreneurs have created safer economic spaces for them and have enabled job opportunities for the waged unemployed labor. The increasing gap between refugees and natives can fuel poverty, segregation in society and the host society can miss out on important potential economic gains from refugee migrants (Bevelander, 2020). Skill development programs for Afghan women is

\section{Economic integration process}


another measure that is suggested. This vocational training will use the human capital that is just wasted for decades. Afghan women are skillful in embroideries, carpet weaving, cooking, sewing and can be a good source of economic opportunity for their community and for Pakistan.

Current study about labor market integration of refugee via family entrepreneurship can benefit from further in-depth studies on this phenomenon, using different methodologies e.g. longitudinal studies, surveys, etc. Fair economic integration of refugees is not possible without structural, institutional setups in the host society (Kloosterman, 2010), therefore the impact of different integration policies and the effect of refugee settlement programs should be comparatively investigated in different host countries. Though statistical data and the number of refugees flow in different countries are widely available, but any data at a governmental level on the integration of refugees is not available for many countries and especially in Pakistan. More statistical data at the government level should be targeted for facilitating future research and understanding of the refugee integration process.

\section{Notes}

1. National Identity Card issuance authority in Pakistan.

2. Native group from the province of KPK Pakistan.

\section{References}

Ager, A. and Strang, A. (2008), "Understanding integration: a conceptual framework", Journal of Refugee Studies, Vol. 21 No. 2, pp. 166-191.

Aldrich, H.E. and Cliff, J.E. (2003), "The pervasive effects of family on entrepreneurship: toward a family embeddedness perspective”, Journal of Business Venturing, Vol. 18 No. 5, pp. 573-596.

Alimia, S. (2014), "Afghan (re)migration from Pakistan to Turkey: transnational norms and the'pull'of Pax-Ottomanica?”, Insight Turkey, Vol. 16 No. 4, p. 159.

Barrett, G.A., Jones, T.P. and McEvoy, D. (1996), "Ethnic minority business: theoretical discourse in Britain and North America”, Urban Studies, Vol. 33 Nos 4/5, pp. 783-809.

Batrouney, T. and Stone, W. (1998), "Cultural diversity and family exchanges”, Family Matters, Vol. 51, pp. 13-20.

Battisti, M., Giesing, Y. and Laurentsyeva, N. (2019), "Can job search assistance improve the labour market integration of refugees? Evidence from a field experiment”, Labour Economics, Vol. 61, p. 101745.

Beckers, P. and Blumberg, B.F. (2013), "Immigrant entrepreneurship on the move: a longitudinal analysis of first-and second-generation immigrant entrepreneurship in The Netherlands", Entrepreneurship and Regional Development, Vol. 25 Nos 7/8, pp. 654-691.

Berry, J.W. (1997), "Immigration, acculturation, and adaptation", Applied Psychology, Vol. 46 No. 1, pp. 5-34.

Berry, J.W. (2001), “A psychology of immigration”, Journal of Social Issues, Vol. 57 No. 3, pp. 615-631.

Berry, J.W. (2003), "Conceptual approaches to acculturation”, in Chun, K.M., Balls Organista, P. and Marín, G. (Eds), Acculturation: Advances in Theory, Measurement, and Applied Research, American Psychological Association, Washington, DC, pp. 17-37.

Bettinelli, C., Fayolle, A. and Randerson, K. (2014), Family Entrepreneurship: A Developing Field, Vol. 10 No. 3, pp. 161-236.

Bevelander, P. (2020), "Integrating refugees into labor markets", Iza World of Labor. 
Bevelander, P. and Pendakur, R. (2014), "The labour market integration of refugee and family reunion immigrants: a comparison of outcomes in Canada and Sweden", Journal of Ethnic and Migration Studies, Vol. 40 No. 5, pp. 689-709.

Bizri, R.M. (2017), "Refugee-entrepreneurship: a social capital perspective", Entrepreneurship and Regional Development, Vol. 29 Nos 9/10, pp. 847-868.

Blood, P.R. (2018), Afghanistan-a Country Study, B\&R Samizdat Express.

Caarls, K. and de Valk, H.A. (2017), "Relationship trajectories, living arrangements, and international migration among Ghanaians", Population, Space and Place, Vol. 23 No. 6, p. e2046.

Cheung, S.Y. and Phillimore, J. (2014), "Refugees, social capital, and labour market integration in the UK”, Sociology, Vol. 48 No. 3, pp. 518-536.

Chrisman, J.J., Chua, J.H. and Steier, L. (2005), "Sources and consequences of distinctive familiness: an introduction", Entrepreneurship Theory and Practice, Vol. 29 No. 3, pp. 237-247.

Chung, H. and Gale, J. (2009), "Family functioning and self-differentiation: a cross-cultural examination", Contemporary Family Therapy, Vol. 31 No. 1, pp. 19-33.

Crul, M. and Pasztor, A. (2007), "Patterns of integration. Between group and within group differences in the dutch context. A contribution to the segmented assimilation debate", Paper presented at the 12th International Metropolis Conference, Melbourne, Australia.

Daily Times (2016), Number of Afghan Refugees in Rawalpindi Crosses 35,000 - Daily Times, Retrieved 06.01.2021.

Dana, L.P. (2001), "Networks, internationalization and policy", Small Business Economics, Vol. 16 No. 2, pp. 57-62.

Dana, L.P. and Light, I. (2011), "Two forms of community entrepreneurship in Finland: are there differences between finnish and sámi reindeer husbandry entrepreneurs?", Entrepreneurship and Regional Development, Vol. 23 Nos 5/6, pp. 331-352.

Dana, L.P. and Morris, M. (2007), "Towards a synthesis: a model of immigrant and ethnic entrepreneurship", Handbook of Research on Ethnic Minority Entrepreneurship: A coEvolutionary View on Resource Management, pp. 803-811.

Dana, L.P., Gurau, C., Light, I. and Muhammad, N. (2020), "Family, community, and ethnic Capital as entrepreneurial resources: toward an integrated model”, Journal of Small Business Management, pp. 1-27.

Danes, S.M., Matzek, A.E. and Werbel, J.D. (2010), "Spousal context during the venture creation process", Advances in Entrepreneurship, Firm Emergence and Growth, Vol. 12, pp. 113-162.

Dannefer, D. (2003), "Cumulative advantage/disadvantage and the life course: cross-fertilizing age and social science theory", The Journals of Gerontology Series B: Psychological Sciences and Social Sciences, Vol. 58 No. 6, pp. S327-S337.

Desai, S., Naudé, W. and Stel, N. (2020), "Refugee entrepreneurship: context and directions for future research”, Small Business Economics, Vol. 25 No. 3, pp. 1-13.

Dhami, S. and Sheikh, A. (2000), "The Muslim family: predicament and promise", Western Journal of Medicine, Vol. 173 No. 5, p. 352.

Discua Cruz, A., Howorth, C. and Hamilton, E. (2013), "Intrafamily entrepreneurship: the formation and membership of family entrepreneurial teams", Entrepreneurship Theory and Practice, Vol. 37 No. 1, pp. 17-46.

Edgcomb, E.L., Klein, J.A. and Thetford, T. (2007), "Pursuing sustainability in the microenterprise field: findings from a literature review by FIELD”, Microenterprise Fund for Innovation, Effectiveness, Learning and Dissemination.

Eisenhardt, K.M. (1989), "Making fast strategic decisions in high-velocity environments", Academy of Management Journal, Vol. 32 No. 3, pp. 543-576. 
Elo, M., Täube, F. and Volovelsky, E.K. (2019), “Migration 'against the tide’: location and Jewish diaspora entrepreneurs”, Regional Studies, Vol. 53 No. 1, pp. 95-106.

Elo, M., Sandberg, S., Servais, P., Cruz, A.D. and Basco, R. (2019), "Entrepreneurship, migration, and family in peripheral contexts: avenues for growth and internationalisation", International Journal of Entrepreneurship and Small Business, Vol. 36 Nos 1/2.

Evansluong, Q. and Ramírez Pasillas, M. (2019), "The role of family social capital in immigrants' entrepreneurial opportunity creation processes", International Journal of Entrepreneurship and Small Business, Vol. 36 Nos 1/2.

Evansluong, Q., Pasillas, M.R. and Bergström, H.N. (2019), "From breaking-ice to breaking-out: integration as an opportunity creation process", International Journal of Entrepreneurial Behavior and Research, Vol. 25 No. 5.

Farwell, N. (2001), “'Onward through strength': coping and psychological support among refugee youth returning to Eritrea from Sudan”, Journal of Refugee Studies, Vol. 14 No. 1, pp. 43-69.

Fong, R., Busch, N.B., Armour, M., Heffron, L.C. and Chanmugam, A. (2007), "Pathways to selfsufficiency: successful entrepreneurship for refugees", Journal of Ethnic and Cultural Diversity in Social Work, Vol. 16 Nos 1/2, pp. 127-159.

Garnham, A. (2006), "Refugees and the entrepreneurial process", Labour, Employment and Work in New Zealand.

Gericke, D., Burmeister, A., Löwe, J., Deller, J. and Pundt, L. (2018), "How do refugees use their social capital for successful labor market integration? An exploratory analysis in Germany", Journal of Vocational Behavior, Vol. 105, pp. 46-61.

Ghufran, N. (2011), "The role of UNHCR and afghan refugees in Pakistan”, Strategic Analysis, Vol. 35 No. 6, pp. 945-954.

Gioia, D.A., Corley, K.G. and Hamilton, A.L. (2013), "Seeking qualitative rigor in inductive research: notes on the Gioia methodology”, Organizational Research Methods, Vol. 16 No. 1, pp. 15-31.

Gioia, D.A. and Pitre, E. (1990), "Multiparadigm perspectives on theory building", The Academy of Management Review, Vol. 15 No. 4, pp. 584-602.

Habbershon, T.G. and Williams, M.L. (1999), "A resource-based framework for assessing the strategic advantages of family firms", Family Business Review, Vol. 12 No. 1, pp. 1-25.

Harb, M., Kassem, A. and Najdi, W. (2019), "Entrepreneurial refugees and the city: brief encounters in Beirut", Journal of Refugee Studies, Vol. 32 No. 1, pp. 23-41.

Hasan, A. (2010), "Migration, small towns and social transformations in Pakistan", Environment and Urbanization, Vol. 22 No. 1, pp. 33-50.

Haug, S. (2008), "Migration networks and migration decision-making”, Journal of Ethnic and Migration Studies, Vol. 34 No. 4, pp. 585-605.

Hilali, A.Z. (2002), "The costs and benefits of the afghan war for Pakistan”, Contemporary South Asia, Vol. 11 No. 3, pp. 291-310.

Jack, S.L. and Anderson, A.R. (2002), "The effects of embeddedness on the entrepreneurial process", Journal of Business Venturing, Vol. 17 No. 5, pp. 467-487.

Kloosterman, R.C. (2010), "Matching opportunities with resources: a framework for analysing (migrant) entrepreneurship from a mixed embeddedness perspective", Entrepreneurship and Regional Development, Vol. 22 No. 1, pp. 25-45.

Lamba, N.K. (2003), "The employment experiences of canadian refugees: measuring the impact of human and social capital on quality of employment", Canadian Review of Sociology/Revue Canadienne de Sociologie, Vol. 40 No. 1, pp. 45-64.

Lancee, B. (2016), "Job search methods and immigrant earnings: a longitudinal analysis of the role of bridging social capital”, Ethnicities, Vol. 16 No. 3, pp. 349-367. 
Lapadat, J.C. (2009), "Writing our way into shared understanding: collaborative autobiographical writing in the qualitative methods class", Qualitative Inquiry, Vol. 15 No. 6, pp. 955-979.

Li, P.S. (2004), "Social capital and economic outcomes for immigrants and ethnic minorities", Journal of International Migration and Integration/Revue de L'integration et de la Migration Internationale, Vol. 5 No. 2, pp. 171-190.

Light, I. and Dana, L.P. (2013), "Boundaries of social capital in entrepreneurship", Entrepreneurship Theory and Practice, Vol. 37 No. 3, pp. 603-624.

McDonald-Wilmsen, B. and Gifford, S.M. (2009), New Issues in Refugee Research.

Manderson, L., Kelaher, M., Markovic, M. and McManus, K. (1998), "A woman without a man is a woman at risk: women at risk in Australian humanitarian programs", Journal of Refugee Studies, Vol. 11 No. 3, pp. 267-283.

Marshall, C. and Rossman, G.B. (2014), Designing Qualitative Research, Sage publications.

Martín, I., Arcarons, A., Aumüller, J., Bevelander, P., Emilsson, H., Kalantaryan, S. and Zorlu, A. (2016), "From refugees to workers: mapping labour market integration support measures for asylum-seekers and refugees in EU member states", Literature Review and Country Case Studies, Vol. 2.

Mawson, S. and Kasem, L. (2019), "Exploring the entrepreneurial intentions of Syrian refugees in the UK", International Journal of Entrepreneurial Behavior and Research, Vol. 25 No. 5.

Meister, A.D. and Mauer, R. (2019), "Understanding refugee entrepreneurship incubation-an embeddedness perspective", International Journal of Entrepreneurial Behavior and Research, Vol. 25 No. 5.

Miles, M.B. and Huberman, A.M. (1994), Qualitative Data Analysis: An Expanded Sourcebook, Sage.

Muhammad, N. and Dana, L.P. (2015), "Collective efficacy of a regional network: extending the social embeddedness perspective of entrepreneurship".

Nannestad, P., Lind Haase Svendsen, G. and Tinggaard Svendsen, G. (2008), "Bridge over troubled water? Migration and social capital", Journal of Ethnic and Migration Studies, Vol. 34 No. 4, pp. 607-631.

Nordqvist, M. and Zellweger, T. (Eds) (2010), Transgenerational Entrepreneurship: Exploring Growth and Performance in Family Firms across Generations, Edward Elgar Publishing.

Park, S.S. and Waldinger, R.D. (2017), "Bridging the territorial divide: immigrants' cross-border communication and the spatial dynamics of their kin networks", Journal of Ethnic and Migration Studies, Vol. 43 No. 1, pp. 18-40.

Piracha, M., Tani, M. and Vaira-Lucero, M. (2016), "Social capital and immigrants' labour market performance”, Papers in Regional Science, Vol. 95, pp. S107-S126.

Ram, M., Theodorakopoulos, N. and Jones, T. (2008), "Forms of capital, mixed embeddedness and Somali enterprise", Work, Employment and Society, Vol. 22 No. 3, pp. 427-446.

Ramadani, V., Bexheti, A., Dana, L.P. and Ratten, V. (2019), "Informal ethnic entrepreneurship: an overview", Informal Ethnic Entrepreneurship, Springer, Cham, pp. 1-7.

Roth, W.D., Seidel, M.D.L., Ma, D. and Lo, E. (2012), "In and out of the ethnic economy: a longitudinal analysis of ethnic networks and pathways to economic success across immigrant categories 1", International Migration Review, Vol. 46 No. 2, pp. 310-361.

Rusinovic, K. (2006), Dynamic Entrepreneurship; First and Second-Generation Immigrant Entrepreneurs in Dutch Cities, University Press, Amsterdam.

Rusinovic, K. (2008), "Transnational embeddedness: transnational activities and networks among firstand second-generation immigrant entrepreneurs in The Netherlands", Journal of Ethnic and Migration Studies, Vol. 34 No. 3, pp. 431-451.

Ryan, L. (2011), "Migrants' social networks and weak ties: accessing resources and constructing relationships post-migration", The Sociological Review, Vol. 59 No. 4, pp. 707-724.

\section{Economic integration \\ process}


Ryan, L., Rodriguez, M.L. and Trevena, P. (2016), “Opportunities and challenges of unplanned follow-up interviews: experiences with polish migrants in London”, In Forum Qualitative Sozialforschung/ Forum: Qualitative Social Research, Vol. 17, p. 2.

Salvato, C. and Melin, L. (2008), "Creating value across generations in family-controlled businesses: the role of family social capital", Family Business Review, Vol. 21 No. 3, pp. 259-276.

Sandberg, S., Immonen, R. and Kok, S. (2019), "Refugee entrepreneurship: taking a social network view on immigrants with refugee backgrounds starting transnational businesses in Sweden", International Journal of Entrepreneurship and Small Business, Vol. 36 Nos 1/2, pp. 216-241.

Schreiner, M. (1999), "Lessons for microenterprise programs from a fresh look at the unemployment insurance self-employment demonstration", Evaluation Review, Vol. 23 No. 5, pp. 504-526.

Schreiner, M. and Woller, G. (2003), "Microenterprise development programs in the United States and in the developing world", World Development, Vol. 31 No. 9, pp. 1567-1580.

Schweitzer, R., Melville, F., Steel, Z. and Lacherez, P. (2006), "Trauma, post-migration living difficulties, and social support as predictors of psychological adjustment in resettled Sudanese refugees", Australian and New Zealand Journal of Psychiatry, Vol. 40 No. 2, pp. 179-187.

Seidel, J. and Kelle, U. (1995), "Different functions of coding in the analysis of textual data", ComputerAided Qualitative Data Analysis: Theory, Methods and Practice, pp. 52-61.

Simich, L., Beiser, M. and Mawani, F.N. (2003), "Social support and the significance of shared experience in refugee migration and resettlement”, Western Journal of Nursing Research, Vol. 25 No. 7, pp. 872-891.

Steier, L. (2009), "Where do new firms come from? Households, family capital, ethnicity, and the welfare mix", Family Business Review, Vol. 22 No. 3, pp. 273-278.

Summerfield, D. (2001), "Asylum-seekers, refugees and mental health services in the UK", Psychiatric Bulletin, Vol. 25 No. 5, pp. 161-163.

Takeda, J. (2000), "Psychological and economic adaptation of Iraqi adult male refugees: implications for social work practice", Journal of Social Service Research, Vol. 26 No. 3, pp. 1-21.

Taras, V., Rowney, J. and Steel, P. (2013), "Work-related acculturation: change in individual workrelated cultural values following immigration", The International Journal of Human Resource Management, Vol. 24 No. 1, pp. 130-151.

Toussaint-Comeau, M. (2005), "Self-employed immigrants: an analysis of recent data", Chicago Fed Letter, No. 213, p. 1.

UNHCR (2020), "Who is a refugee?”, available at: www.unrefugees.org/refugee-facts/what-is-a-refugee/

Van Doorn, M., Scheepers, P. and Dagevos, J. (2013), "Explaining the integration paradox among small immigrant groups in The Netherlands", Journal of International Migration and Integration, Vol. 14 No. 2, pp. 381-400.

Vinokurov, A., Trickett, E.J. and Birman, D. (2017), "Community context matters: acculturation and underemployment of Russian-speaking refugees", International Journal of Intercultural Relations, Vol. 57, pp. 42-56.

Ward, C.A., Bochner, S. and Furnham, A. (2001), The Psychology of Culture Shock, Psychology Press.

Wauters, B. and Lambrecht, J. (2008), "Barriers to refugee entrepreneurship in Belgium: towards an explanatory model", Journal of Ethnic and Migration Studies, Vol. 34 No. 6, pp. 895-915.

\section{Further reading}

Chrysostome, E. and Lin, X. (2010), "Immigrant entrepreneurship: scrutinizing a promising type of business venture", Thunderbird International Business Review, Vol. 52 No. 2, pp. 77-82.

Danes, S.M., Lee, J., Stafford, K. and Heck, R.K.Z. (2008), "The effects of ethnicity, families and culture on entrepreneurial experience: an extension of sustainable family business theory", Journal of Developmental Entrepreneurship, Vol. 13 No. 03, pp. 229-268. 
Discua Cruz, A.F. and Fromm, I. (2019), "Understanding the emergence of a social enterprise by highly skilled migrants: the case of Honduras Global Europa”, International Journal of Entrepreneurial Behavior and Research, Vol. 25 No. 5, pp. 801-818.

McDougall, P.P. and Oviatt, B.M. (2000), "International entrepreneurship: the intersection of two research paths", Academy of Management Journal, Vol. 43 No. 5, pp. 902-906.

Randerson, K., Bettinelli, C., Fayolle, A. and Anderson, A. (2015), "Family entrepreneurship as a field of research: exploring its contours and contents", Journal of Family Business Strategy, Vol. 6 No. 3, pp. 143-154.

Ram, M. and Smallbone, D. (2003), "Policies to support ethnic minority enterprise: the English experience", Entrepreneurship and Regional Development, Vol. 15 No. 2, pp. 151-166.

Raza, M., Beaujot, R. and Woldemicael, G. (2013), "Social capital and economic integration of visible minority immigrants in Canada", Journal of International Migration and Integration, Vol. 14 No. 2, pp. 263-285.

\section{Corresponding author}

Khizran Zehra can be contacted at: k.zehra@uvt.nl

For instructions on how to order reprints of this article, please visit our website: 